\title{
WHEN ARE LAYOFFS ACCEPTABLE? EVIDENCE FROM A QUASI-EXPERIMENT
}

\author{
by \\ Gary Charness \\ Department of Economics and Business \\ Universitat Pompeu Fabra \\ 25-27 Ramon Trias Fargas \\ 08005 Barcelona, Spain \\ charness@upf.es \\ and \\ David I. Levine \\ Haas School of Business \\ University of California \\ Berkeley, CA 94720-1900 \\ (510) 642-1697 \\ levine@haas.berkeley.edu
}

Keywords: New employment contract, fairness, justifications, layoffs, survey

JEL Classifications: A13, C93, J41, J50,L14

Acknowledgements: Daniel Kahneman was extremely generous in sharing the KKT research protocols with us. Toshi Akutsu, Mark Gilkey, Adriana Kugler, Daniel Levine, Chad Slawner, and George Strauss provided helpful comments. Comments, data collection and analysis by students in Haas's Business Administration 24 class enriched the paper. The Russell Sage Foundation and the Institute of Industrial Relations and the Clausen Center for International Business and Policy at U.C. Berkeley provided financial support. 


\begin{abstract}
Many authors have discussed a decline in internal labor markets and an apparent shift to a new employment contract, characterized by less commitment between employer and employee and more portable skills. These discussions occur without much evidence on what employment contract employees currently feel is fair. We performed quasi-experimental surveys to study when employees in the U.S. and Canada feel that layoffs are fair.

Layoffs were perceived as more fair if they were due to lower product demand than if the result of employee suggestions. This result appears to be solely due to norms of reciprocity (companies should not punish employees for their efforts), rather than norms of sharing rents, as new technology was also considered a justification for layoffs. Consistent with theories of distributive and procedural equity, layoffs were perceived as more fair if the CEO voluntarily shared the pain. CEO bonuses due to layoffs lowered their reported fairness only slightly.
\end{abstract}

Respondents in Silicon Valley were not more accepting of layoffs than were those in Canada on average, although the justifications considered valid differed slightly. 


\section{INTRODUCTION}

The implicit employment contract can have large effects ranging from productivity to unemployment and inequality. Since the mid-1980's, a number of business scholars, journalists, and labor economists have written on a "new employment contract" with lower employee-employer commitments. To the extent that this new contract is generally accepted, it should influence the degree to which various actions are considered fair.

Our study examines some of the determinants of fairness in labor practices and whether there is evidence that the norms of this new employment contract are generally accepted. We build on the work of Kahneman, Knetsch, and Thaler (1986, KKT) which examined Canadian respondents' views on fairness in wage determination. We extended their study in two ways.

First, examine the fairness of layoffs to examine this important aspect of the employment contract. It is crucial to understand the quantity aspects of the employment contract as well as the price aspects; that is, resistance to layoffs as well as to wage cuts. Policy-makers and managers both have an interest in understanding citizens' perceptions of when layoffs are fair.

Second, we replicated the study in Silicon Valley, to look for differences between regions with stronger and weaker traditions of acceptance of the market. ${ }^{1}$ This element is important because it may be that Canadian results do not hold in the (somewhat) different culture of the United States. Understanding differences (or lack thereof) in attitudes in the U.S. and Canada is crucial in understanding policies ranging from site location of factories to the future of NAFTA.

\section{Employment Contracts, New and Old}

According to numerous authors (e.g., Hackett, 1996), the old employment contract for core employees at large employers had the following provisions:

We expect loyalty from our core mid-level employees, and we provide loyalty in return. If you work hard, and receive satisfactory performance ratings, your job is secure. (We might take exception if the financial health of the company is threatened.)

At a small number of large and visible employers (most notably IBM, but also AT\&T, Hewlett-Packard, and a few dozen others [Foulkes, 1980]), this contract was both

\footnotetext{
${ }^{1}$ A companion paper (Charness and Levine, 1998) examined changes over the last fifteen years in the paycutting scenarios studied by KKT. In general, respondents were not more likely to find pay cuts fair in 1997-98 than KKT found in 1984-85.
} 
generations old, and supplemented with provisions that managers and professionals agreed to move or be retrained.

Many authors have expressed the view that we are in the midst of a major shift away from internal labor markets and toward a new employment paradigm, characterized by greater employee mobility and diminished ties between employer and employee. For example, the Academy of Management Executive recently devoted a special issue to the new employment contract and its effect on careers (1996). The new contract is said to be particularly prevalent in the professional and technical areas.

In contrast to the old contract, the new employment contract has the following provisions:

The work you do will be interesting, and you will learn new skills while you are here. Your employability will be high, although perhaps not at this employer. We work on great projects, but as each project ends, it is up to you to- find a new place for yourself within the company -- otherwise, you must find a new place for yourself outside the company.

So far, the evidence of any large-scale shift from the old to the new model is suggestive, but not conclusive. For example, there has been a decline in job stability for prime-aged men (Rose, 1995; Farber, 1996). At the same time, average tenure has not declined much (e.g., Farber, 1995; Neumark, et al., 1997). On average employees report lower perceptions of job security and believe employers are less loyal than they used to be (Cappelli, et al., 1997). At the same time, Americans did not report lower trust in their employer in 1997 than in 1989 (Kruse and Blasi, 1998: 22-23). Several prominent large employers such as IBM and Kodak have weakened their commitment to long-term employment, and human resource executives at many large employers report a shift from the stereotypical old employment contract to the new [Hackett, 1996]. At the same time, at the same time, such commitments never covered more than a few percent of the workforce. ${ }^{2}$ There is some evidence of more use of bonuses and other flexible forms of pay (O’Shaughnessy, Levine and Cappelli, 1998). At the same time, pay structures at large employers are not more flexible over time and space than they used to be (Belman and Levine, 1998; Groshen and Levine, 1998).

Our study seeks evidence that the new employment contract is manifested in telephone survey respondents' attitudes about the fairness of various layoff scenarios.

\footnotetext{
2 Interestingly, far more HR executives report a shift away from the old high-loyalty contract than work at employers that ever had reputations for implicitly promising job security: compare Hackett, 1996 and Foulkes, 1980).
} 


\section{Perceptions of Fairness of the Employment Contract}

An employee's productivity depends on his or her perception of the underlying social contract with the employer, as well as by narrowly economic concerns (Barnard, 1938; Blau, 1964; Gouldner, 1954). Recently, economists have also begun to focus on the implications of this view. Milgrom and Roberts (1992) point out that "the employment contract is typically quite imprecise;" Williamson (1975) speaks of "atmosphere;" Baker, Murphy, and Jensen (1988) stress the role of trust and loyalty; and Simon (1991) notes that people in organizations do all sorts of things without receiving any specific reward. ${ }^{3}$

An implication of this approach is that perceptions of fairness can matter. A dissatisfied worker may deliberately restrict output or even resort to sabotage. "In simple English, if people do not get what they think they deserve, they get angry." (Akerlof and Yellen, 1990: 260-1) Conversely, an employee who feels he or she receives a fair deal is more likely to perform above any minimum requirements (Levine, 1992).

Recent evidence supports the view that non-pecuniary considerations affect productivity. Levine (1993) shows that compensation executives make simulated decisions as if they believe fairness matters. For example, they do not give lower relative or nominal wage increases when unemployment is high. Moreover, in interviews they support this logic for their decisions. Rabin (1993) surveyed the literature more broadly and suggests that reciprocity is an important norm in determining fairness -- people do not usually believe it is fair when harsh actions follow cooperative ones. Experimental evidence also supports this reasoning. Fehr, Kirchsteiger, and Riedl (1993) and Fehr, Kirchler, Weichbold, and Gachter (1998) find that employees respond to higher (above-market) wages with higher effort, even in an anonymous environment where reputation cannot be a factor. Charness (1998) finds that reciprocity is a significant factor in the level of costly effort an employee chooses. Specifically, effort increases more when wages increase when "employees" knew a self-interested employer chose the wage than when the wage was chosen randomly or by an external entity.

While the experiments related to observable effort, it is likely that most employees have more discretion to react in terms of extra-role behavior such as organizational citizenship behaviors (OCB, Organ 1988). OCB involves behavior that is above and beyond the call of duty, is discretionary, and not rewarded by an organization's formal reward structure. A number of studies have found that OCB is higher when employees perceive more fairness, especially procedural justice (e.g., Farh, Podsakoff, and Organ, 1990; Konovsky, Pugh 1994; Moorman 1991). Other studies provide fairly consistent evidence that OCB relates to organizational performance (e.g., MacKenzie, Podsakoff, and Fetter 1991; Podsakoff, Ahearne, and

\footnotetext{
${ }^{3}$ Akerlof (1982), Akerlof and Yellen (1990), and Levine (1992) presented models that incorporate social factors such as perception of fair treatment. Rousseau (1995) provides an overview of psychological approaches to the employment contract.
} 
MacKenzie, 1997). The implication is that organizations have an incentive to maintain what employees perceive to be a fair employment contract.

Given that perceptions of fairness may matter, what evidence exists concerning community standards of fairness in the employment relationship? In the mid-1980's, Kahneman, Knetsch, and Thaler conducted a series of quasi-experiments to investigate perceptions of fair treatment in Vancouver and Toronto. They found that reductions in wages due to slack labor markets were considered unfair for current employees much more frequently than identical cuts in pay for new employees.

The literature on procedural justice emphasizes that not just the level of pay, but also the causes and processes for changing it can affect employees' reactions (Lind and Tyler, 1988; Leventhal, 1976). Among other factors, theories of procedural justice emphasize that most respondents consider procedures more fair if the decision-maker treats the respondent with respect, has no vested interest in a decision that is harmful to the respondent, and has limited choice in making a decision.

The latter factor implies that changes in the economic context can affect the sense of entitlement. For example, Kahneman, Knetsch and Thaler found that shocks that reduce profits justify new wages, but that increases in market power do not. While $77 \%$ of respondents consider it unfair for a company that has been making money to reduce wages by $5 \%$ (even if it could easily replace workers with others at the lower wage), $68 \%$ thought that this wage reduction was acceptable if the company were losing money. More generally, Shore and Tetrick sum up the research on violations of perceived employment contracts by noting the importance of how employees assess responsibility for unmet obligations:

People make attributions of responsibility when they make judgments of fairness. If an organization appears to break the psychological contract voluntarily, judgments of injustice may be greater than when the organization is not held fully responsible. For example, a psychological contract representing organizational obligations of job security in exchange for employee obligations to be loyal, which is broken (e.g. when an employee is fired or part of a layoff) may be viewed as only a partially broken contract if an economic downturn caused the organization to be unable to fulfill the obligation. In addition, when the organization claims that they cannot completely fulfill a contract, but attempts to partially do so (e.g. early voluntary retirement rather than a layoff), this voluntary attempt may lessen perceptions of a violation. (1994: 104)

Rousseau and her colleagues used quasi-experiments to examine the perceived fairness of layoffs (Rousseau and Anton 1988, 1991; Rousseau and Aquino 1993). Respondents felt that layoffs were less fair when employees had high seniority and when employers' had made commitments to long-term employment.

We replicated a number of the results of Rousseau and her colleagues, and extended their research in several ways. First, while they surveyed students and part-time students 
(typically mid-level managers in their full-time jobs) at elite business schools, we examined a random cross-section of several cities. Thus, their results reflect largely the opinions of those making (or soon to be making) downsizing decisions; our results are more representative of the opinions of those being downsized and their colleagues who survive the layoffs. Both sets of perceptions are important for understanding the economy.

Rousseau and her co-authors largely used a within-subjects design, comparing how respondents rated several dozen scenarios. We used a between-subject design, in which all of the contrasts are between scenarios given to different subjects. The between-subjects method reduces demand effects, where respondents respond to match what they believe the experimenter feels is fair.

Rousseau used a study design that approximated using all possible combinations of conditions. This method led to some unrealistic scenarios, such as employers that frequently terminated competent employees but had a formal commitment of long-term employment (Rousseau and Anton, 1988: 279). Our design avoided such scenarios.

Finally, we added a number of conditions such as the changes in CEO pay due to the layoffs (as in Bies, Tripp and Neale, 1993; conversely, previous quasi-experiments have examined conditions that were not included in this one.

This study also builds on the surveys conducted by Brockner and his co-authors (1994). They explored employee reactions to layoffs as a function of distributional (the respondents' cost of being laid off) and procedural (e.g., length of advanced warning) elements of treatment. Their study covered actual victims or survivors of layoffs, while this study covers a representative sample of respondents. This study has the advantage of a quasi-experimental design, while their surveys were purely correlational. We examine more dimensions of the layoff and its environment, while their study examined specifically the interaction of distributional and procedural elements of justice. Thus, the studies are complementary.

\section{SURVEY METHODOLOGY}

We asked each respondent two or three questions about standards of fairness in layoffs. ${ }^{4}$ Comparison questions were asked of different respondents. This design minimizes respondents' inclination and ability to answer based on their attempts to guess the researchers' hypotheses. These are listed in Appendix A. In order to ensure statistical significance for any observed substantial changes, we collected approximately 125 replies for each question. Telephone calls were made to random listings in area directories, using a standard script. Following the standard

\footnotetext{
${ }^{4}$ We also asked each respondent two questions concerning when pay cuts were fair. The questions were taken from Kahneman, Knetsch, and Thaler (1986), and results are reported in Charness and Levine (1999).
} 
within this literature, we refer to actions as "fair" when respondents have reported the descriptions of actions as fair.

We first carried out the study in Vancouver and Toronto cities between March and September 1997. We then replicated the survey in Silicon Valley between October 1997 and March 1998.

We studied how changes in the sources of the shocks to the employer, the reactions of the employer, the skills and occupations of the employees affected, and other factors affected respondents' perceptions of fairness. The questions concerning layoffs examined variations of a model case:

A company faced lower product demand due to shifts in the market; the viability of the employer is threatened. In response, the company laid off some high-technology engineers with an average of ten years of tenure at this employer. Before the layoff, the employer gave each employee four paid weeks to find another job elsewhere in the company. Those who could not find a new position received severance pay based on age and years of service. The company provided out-placement assistance including counseling and résumé-writing workshops. Employees knew layoffs were likely in this circumstance.

We varied this model case along a number of dimensions. We examined how respondents' changed their views about the fairness of the employer if the source of lower labor demand was higher productivity due to employees' suggestions or due to new technology, instead of product market shocks, and if the company had layoffs with less notice or avoided layoffs altogether, instead of the "gentle" layoffs described above. We compared results if the occupation of the employees were production workers instead of engineers. In the Silicon Valley surveys, we added the dimension of general vs. firm-specific skills. We also varied whether CEO pay either rose due to cost cutting from layoffs or was declined by the CEO to share the pain.

Our scenarios covered two occupations with different gains or losses from the new employment contract. The first was an occupation for whom the new contract was designed: high-technology engineers with ten years of tenure at this employer. The second was more vulnerable to the new employment contract: production workers who have specialized in this company's unusual technology, with an average of ten years of tenure at the employer.

We discuss mean responses after coding the responses on a cardinal scale ranging from $3=$ "completely fair" to $0=$ "very unfair." Results were unchanged using nonparametric tests that did not impose cardinality on the responses.

\section{HYPOTHESES}


We have a number of hypotheses concerning employee perceptions of employment practices:

\section{What shocks justify layoffs?}

The scenarios examined several different shocks that reduce the employer's demand for labor:

a. Lower product demand due to shifts in the market; the viability of the employer is threatened.

b. Higher productivity due to new technology.

c. Higher productivity due to employees' suggestions.

d. The employee's current project has ended. ${ }^{5}$

In general, people consider it fairer to react to an exogenous shock than to take the initiative and cause harm (see the citations in Rabin 1993). Along these lines, KKT found that circumstances threatening the existence of the firm led many people to consider pay cuts as fair. Similarly, Brockner (1992) noted how employees perceive layoffs as less problematic when they are necessary due to external circumstances. Thus, we assume that layoffs will be largely perceived of as fair when the employers' health is threatened by declining product demand.

New technology is less exogenous to the employer than lower product demand. Thus, respondents should rate layoffs in response to the product demand shock as fairer than those due to the technology shock. Moreover, new technology that raises productivity increases the employers' ability to pay. To the extent that perceptions of fairness involve the sharing of rents and quasi-rents, layoffs due to the introduction of new technology should be perceived of as less fair than layoffs due to lower product demand.

Like new technology, employees' suggestions increase employers' ability to pay. Layoffs due to employees' suggestions have yet another reason to be perceived of as unfair: they violate the norm of reciprocity. The norm of reciprocity suggests that employers should respond to employee suggestions with bonuses, not with layoffs. For respondents who share this view, layoffs for this reason should be even less fair than those due to new technology.

These considerations lead to:

\footnotetext{
${ }^{5}$ Follow-up interviews led us to believe that respondents did not interpret this condition as we had intended. That is, the scenario we had in mind was of a company with employees who moved from project to project. In the "old" employment contract, the employer found new positions for employees as each project ended (e.g., a new version of a product shipped). In the "new" contract, employees must seek new employment within the enterprise or outside of it as each project ends. Apparently, some respondents had in mind a different scenario where the employee was hired for a single project, the employer had no ongoing or starting up projects, and then the single project ended. This ambiguity led us drop a separate analysis of this condition, although we did retain these respondents for other conditions.
} 
Hypothesis 1: Layoffs are usually perceived as fair in cases of lower product demand (shock a), sometimes fair for the introduction of new technology (shock b), and usually unfair for employees' suggestions (shock c).

\section{When are "gentle" layoffs fair?}

Our scenarios considered three possible responses to a reduction in labor demand.

Layoffs ("gentle"): The company is laying off some employees. Before the layoff, the employer has given each employee four paid weeks to find another job elsewhere in the company. Those who cannot find a new position receive severance pay based on age and years of service. The company provided out-placement assistance including counseling and résumé-writing workshops. Employees knew layoffs were likely in this circumstance.

Layoffs ("harsh"): The company is laying off employees with two weeks' warning. These are the first layoffs of [occupation] in the company's history.

Hoard labor: The employer promises to avoid laying off employees, although many employees will need to be retrained in a new job, and employees may need to relocate to a different city.

The "gentle" layoffs scenario is significantly more generous than the harsh layoff scenario. Brockner, for example, notes that layoffs are perceived as less unfair when the employer provides tangible care-taking services to help soften the blow. This reasoning leads to:

Hypothesis 2a: Gentle layoffs are perceived as significantly more fair than harsh layoffs.

More interestingly, the literature on new employment contract suggests that gentle layoffs are always fair. It is possible that, unlike harsh layoffs, respondents do not consider these gentler layoffs as violating norms of reciprocity, even when employees have submitted productivityenhancing ideas. This reasoning leads to:

Hypothesis $2 b$ : In contrast with hypothesis 1 , the type of shock makes little difference in how fairly respondents rate gentle layoffs. (That is, harsh layoffs will be considered very unfair after employee suggestions, but not too unfair after demand shocks; in contrast, gentle layoffs will be considered not too unfair in any case.)

Hoarding labor is the strongest form of employment security an employer can provide. In this case, we assume hoarding labor may involve need for retraining or relocation. These were the preconditions of large Japanese and US employers who provided employment security. 
(Recall the joke that "IBM" stood for "I've Been Moved.") If the old employment contract was fair, then we have

Hypothesis 2c: Hoarding labor, even if it means retraining and relocation, is considered fair for every shock.

\section{The Role of CEO Bonuses}

Theories of distributive justice often imply that lower-paid employees look to the fate of their higher-paid colleagues for fairness comparisons. In some cases, these comparisons rise to the highest ranks of the organization. (Cowherd and Levine survey this literature [1992].) One such setting when the CEO is a salient referent may be during downsizing.

For example, one high-technology company announced its CEO's record compensation the same week they announced layoffs. The employees were outraged. Email on the companies internal computer network contained messages such as "Morale is somewhat like it must have been just before the French Revolution; everyone wants to overthrow the royalty." (Bishop and Levine detail this case [1998].)

Theories of procedural justice amplify this argument (Bies, Tripp and Neale, 1993). People are more likely to consider a decision fair, even if it harms them, if the decision-maker did not profit from it. Conversely, if a decision-maker profits from a decision that harms employees, they have reason to doubt the objective basis of the decision (Leventhal, 1976).

At the same time, some analysts have emphasized the potential benefits to shareholders that can follow from rewarding CEOs for cutting costs (Dial and Murphy, 1995). This result depends heavily on whether the remaining employees perceive the CEO pay as fair or not, and on employees' reaction to any perceived unfairness.

In fact, the reaction of layoff survivors appears to depend in part on the perceived fairness of the layoffs. Brockner (1992) claims that employees' perceive layoffs as more fair when cutbacks were shared at higher managerial levels. These findings lead to:

Hypothesis 3a: Perceived fairness will increase when the CEO turned down his bonus this year because of the unexpected need for layoffs.

Hypothesis $3 b$ : Perceived fairness will decrease when layoffs occur due to lower market demand or higher productivity, and the CEO received a record bonus for his success in introducing the new technology or cutting costs.

\section{The Role of Skill Specificity and Occupation}

Employees' costs of layoffs are higher when employees have employer-specific skills than when they have skills that are widely useful (Becker, 1975). Thus, people are more likely to 
consider the former set of layoffs less fair. (Rousseau and Anton provide further theoretical justification for this hypothesis $(1988,1991)$, although in their quasi-experiment whether it would be hard vs. easy to find another job was not a significant predictor of perceived fairness.)

Hypothesis 4a: Layoffs are more fair when the affected workers or engineers "specialize in widely used hardware, so that their skills would be useful in another job" than when they "are specialists in this company's unusual technology."

Although rates are converging, production employees remain more likely to be laid off than are professional employees (Farber, 1996). Substantial evidence indicates that many people find what is common becomes perceived as fair. Moreover, professionals typically have a highertrust relationship with the employer, providing higher commitment and working with lower monitoring. In exchange, so goes the reasoning of the traditional employment contract, the employer is supposed to provide stable employment.

To the extent that what is common becomes perceived as fair or that professionals are working under an employment contract with higher security, we have the following hypothesis:

Hypothesis $4 b$ : Layoffs are more fair when they affect production workers than engineers.

\section{Canada vs. Silicon Valley}

Compared to the United States, for most of this century Canada has been associated with a stronger welfare state, a more active government, and lower legitimacy for market forces (Lipset, 1990; Card and Freeman, 1993). ${ }^{6}$ Silicon Valley, in contrast, is an unusual region with a history of low unemployment and high mobility among skilled engineers. Moreover, the rhetoric of the new employment contract was clearly annunciated by some Silicon Valley employers such as Apple Computers (e.g., Sculley, 1995: 92-99). This history leads to:

Hypothesis 5a: Layoffs will be perceived as more fair in Silicon Valley than in Canada (specifically, Vancouver and Toronto).

These historical and cultural differences may have been increased by differences in unemployment rates. In November 1997, the unemployment rate in the San Jose CA metropolitan area was only $2.6 \%$, below the already-low US average of 4.1 percent (US BLS 1998). In Canada, in contrast, average unemployment rates were substantially higher than in the US, running about 8.9 percent. The rates in Vancouver and Toronto were similar to, though slightly

\footnotetext{
${ }^{6}$ We surveyed only in English-speaking Canada; specifically, Vancouver and Toronto. In past studies, attitudes toward work and employers in anglophone Canada have been more similar to those of the US than are those of francophone Canada. Thus, it is likely the perceived fair contract would be more different between Quebec and Silicon Valley (Lipset, 1990).
} 
lower than, the national rates (Statistics Canada, 1999). To the extent people find layoffs less fair when the cost of job loss is high, the US-Canada differences should be increased by the muchhigher Canadian unemployment rates. (Alternatively, if being in a region with many layoffs increases the perceived fairness of layoffs, then the high unemployment rates in Canada may have inured respondents to layoffs, and increased perceptions of the fairness of layoffs.)

We chose Silicon Valley because is not representative of the United States as a whole, but probably is more accepting of the new employment contract. Thus, the tests below provide a one-sided test for US-Canada differences; even if respondents in Silicon Valley are more accepting of the new contract than respondents in Vancouver and Toronto, most of the U.S. may be more similar to the Canadian cities.

Conversely, francophone Quebec has a very different history and somewhat different culture than the rest of Canada. In many studies, respondents in Quebec often are less accepting of the market and are more different from U.S. respondents than are anglophone Canadians (Lipset, 1990). Thus, any findings of U.S.-Canada similarity may not generalize to francophone Canada.

In Silicon Valley, layoffs of professionals such as engineers are relatively common events. $^{7}$ Moreover, for most of the last several decades, unemployment rates for engineers in the Valley have been quite low, often less than $1 \%$. If a low cost of job loss makes layoffs more fair, we have the following hypothesis:

Hypothesis 5b: Compared to layoffs for production employees, layoffs of engineers will be perceived as more fair in Silicon Valley than in Canada.

\section{RESULTS}

Summaries of results are presented in Table 1. Many, but not all, of the hypotheses were supported in both Canada and Silicon Valley.

Table 1 presents the means of each question. Although these are presented as though the data were cardinal, in fact the comparisons between questions and nations are performed with the nonparametric Wilcoxon-Mann-Whitney rank-sum test (Siegel and

\footnotetext{
${ }^{7}$ To get a feel for the frequency of publicly visible announcements, we searched the Computer Database produced by Information Access Company for articles concerning layoffs at computer companies. In the relatively prosperous year of May 4, 1997 to May 4, 1998 (chosen to be the most recent at the time of the search), 46 articles appeared with the word "layoff" in the title. The list included former bastions of the "old" contract such as IBM and DEC, innovators in creating the new contract such as Apple, and new software companies that have always grown up with an atmosphere of exciting prospects coupled with low job security such as Netscape, Sybase, and Informix. This quick literature review is merely suggestive. On the one hand, many of the layoffs were not specifically in Silicon Valley. On the other hand, many smaller employers that closed down or laid off employees would not have merited articles in this database.
} 
Castellan, 1988), as the parametric assumptions of t-tests are not fully satisfied. ${ }^{8}$ These results are easy to read and we focus on them in the text; Appendix 2 contains the full tabulations. The Wilcoxon signed-ranks test makes no assumptions about the spacing of the intervals that make up the ordinal scale.

\section{Table 1: What affects the fairness of layoffs?}

Mean perceived fairness: $3=$ completely fair, $0=$ very unfair.

\begin{tabular}{|c|c|c|c|c|c|}
\hline & Canada & $\begin{array}{l}\text { Silicon } \\
\text { Valley }\end{array}$ & $\begin{array}{l}\text { S.V.- } \\
\text { Canada }\end{array}$ & Scenarios & $\begin{array}{l}\text { \# obs. } \\
\text { Can/S. } \\
\text { V. }\end{array}$ \\
\hline \multicolumn{6}{|l|}{ Source of shock } \\
\hline Declining product demand & 1.71 & 1.58 & -.13 & $\mathrm{~F}, \mathrm{M}$ & $270 / 253$ \\
\hline New technology & 1.57 & 1.71 & .14 & $\mathrm{D}, \mathrm{E}$ & $240 / 256$ \\
\hline Employees' suggestion & 1.37 & 1.39 & .02 & $\mathrm{~L}, \mathrm{I}$ & $224 / 278$ \\
\hline Project has ended & 1.75 & 1.56 & $-.18 *$ & $\mathrm{~J}, \mathrm{~S}$ & $216 / 272$ \\
\hline Technology - product demand & -.14 & .13 & $.27^{*}$ & & \\
\hline Product demand - suggestions & $.34 * *$ & .19 & -.15 & & \\
\hline Technology - suggestions & $.20 *$ & $.32 * *$ & .12 & & \\
\hline Combined other shocks - suggestions & $.31 * *$ & $.22 *$ & .09 & & \\
\hline \multicolumn{6}{|l|}{$\begin{array}{l}\text { Employer reaction } \\
\text { (Focal scenario has demand shock, } \\
\text { professionals, and special skills) }\end{array}$} \\
\hline Hoard labor & 2.67 & 2.01 & $-.66^{* *}$ & $P$ & $24 / 138$ \\
\hline "Gentle" layoffs & 2.55 & 2.12 & $-.43 * *$ & E & $131 / 133$ \\
\hline "Harsh" layoffs & .92 & .98 & .05 & $\mathrm{M}$ & $139 / 120$ \\
\hline Hoard - gentle & .12 & -.11 & $-.23^{*}$ & & \\
\hline Gentle - harsh & $1.63^{* *}$ & $1.15^{* *}$ & $-.48 * *$ & & \\
\hline \multicolumn{6}{|l|}{$\begin{array}{l}\text { (Pooling sources of shocks \& } \\
\text { characteristics of employees) }\end{array}$} \\
\hline Gentle & 2.35 & 2.03 & $-.31 * *$ & $\mathrm{E}, \mathrm{I}, \mathrm{J}, \mathrm{M}$ & $468 / 544$ \\
\hline Harsh & .88 & 1.05 & $.17 * *$ & $\mathrm{D}, \mathrm{F}, \mathrm{L}, \mathrm{S}$ & $482 / 515$ \\
\hline Gentle - harsh & $1.46 * *$ & $1.00 * *$ & $-.48 * *$ & & \\
\hline
\end{tabular}

\footnotetext{
${ }^{8}$ We also performed t-tests and obtained similar results. Fortunately, "when respondents are asked to rate on both bipolar adjective [a scale with endpoints marked and equally spaced points in between] and semantic scales [as we use], the results are almost identical... Hence, for practical purposes, either scale is equally useful if intervally scaled data are needed" (Lehman, et al., 1998: 243).
} 


\begin{tabular}{|c|c|c|c|c|c|}
\hline \multicolumn{6}{|l|}{ CEO Pay response } \\
\hline CEO bonus record high & $\mathrm{n} / \mathrm{a}$ & 0.90 & $\mathrm{n} / \mathrm{a}$ & $\mathrm{H}, \mathrm{Q}$ & 272 \\
\hline CEO bonus not mentioned & 0.92 & 1.00 & 0.08 & $\mathrm{D}, \mathrm{F}$ & $238 / 262$ \\
\hline CEO bonus refused & $\mathrm{n} / \mathrm{a}$ & 1.48 & $\mathrm{n} / \mathrm{a}$ & $\mathrm{C}, \mathrm{N}$ & 247 \\
\hline Bonus high - not mentioned & & $-0.10^{*}$ & & & \\
\hline Bonus refused - not mentioned & & $0.48^{* *}$ & & & \\
\hline \multicolumn{6}{|l|}{ Type of skills ${ }^{\mathrm{a}}$} \\
\hline Employer-specific & $\mathrm{n} / \mathrm{a}$ & 1.15 & $\mathrm{n} / \mathrm{a}$ & $\mathrm{F}, \mathrm{G}, \mathrm{K}, \mathrm{S}$ & 517 \\
\hline Generally useful & $\mathrm{n} / \mathrm{a}$ & 1.33 & $\mathrm{n} / \mathrm{a}$ & $\mathrm{A}, \mathrm{B}, \mathrm{O}, \mathrm{R}$ & 540 \\
\hline Specific - General skills & & $-0.18^{* *}$ & & & \\
\hline \multicolumn{6}{|l|}{ Type of employee ${ }^{\mathrm{a}}$} \\
\hline Professional & 0.95 & 1.11 & 0.16 & $F, S$ & $246 / 257$ \\
\hline Production & 1.12 & 1.18 & 0.06 & G, K & $228 / 260$ \\
\hline Professional - Production & $-0.17^{*}$ & -0.07 & 0.10 & & \\
\hline \multicolumn{6}{|c|}{$\begin{array}{l}\text { Notes: Appendix } 1 \text { contains full text of the questions. } \\
* \text { and ** represent statistically significantly differences at the } 5 \text { and } 1 \text { percent level on a Wilcoxon sign-rank } \\
\text { test (two-tailed) for one-way comparisons, and on a two-tailed t-test for differences in differences Results } \\
\text { may not sum due to rounding. }\end{array}$} \\
\hline If only one sample size is given, the & was aske & ly in the & & & \\
\hline
\end{tabular}

\section{What shocks justify layoffs?}

The results provide mixed support for the hypothesis that reciprocity and ability to pay mattered in determining the fairness of layoffs (Hypothesis 1).

As expected, layoffs were viewed as more fair when due to declining product demand (1.71 in Canada, 1.58 in US, $3=$ completely fair, $0=$ very unfair.) -- an exogenous shock -- than when due to employees' suggestions (1.37 in Canada, 1.39 in US). This supports the hypotheses that layoffs are not considered fair when the employers' ability to pay is high and/or when the layoffs violate norms of reciprocity.

More surprisingly, layoffs due to technological change were at least as acceptable (1.57 in Canada, 1.71 in US) as layoffs due to a negative product demand shock (difference between source of shocks n.s.). Thus, it appears that the violation of a reciprocity norm (not punishing employees who have given a gift of new ideas), rather than rentsharing, is responsible for the lower perceived fairness of layoffs.

\section{When are "gentle" layoffs fair?}

Hypothesis 2a posited that the "gentle" layoffs scenario (with advance notice, attempts to find alternative placement, and so forth) would be perceived as significantly more fair than harsh 
layoffs (two weeks warning, unexpected). Consistent with this hypothesis, on average, gentle layoffs were rated midway between completely fair and acceptable in Canada (2.35), and acceptable in the U.S. (2.03). Harsh layoffs were consistently rated as unfair (near 1 on the zero-to-three scale).

Importantly, the literature on new employment contract suggests layoffs, even following employees' suggestions, will be seen as more consonant with norms of reciprocity when employers try to cushion the blow. Thus, Hypothesis $2 \mathrm{~b}$ posited that the type of shock makes little difference in how fairly respondents rate gentle layoffs. The hypothesized interaction was that gentleness of layoffs would be more important for layoffs created by employee suggestions than for layoffs motivated by downturns in demand.

For both Canada and Silicon Valley, the gaps in perceived fairness between harsh and gentle layoffs is slightly smaller for layoffs following suggestions (1.36 and 0.86 points) than the gap for layoffs following demand shifts (1.63 and 1.14 points). These results do not support the hypothesis that gentleness matters more when suggestions lead to layoffs. (The gap for layoffs following the introduction of new technology was slightly smaller for Canada, 1.32 points, and slightly larger in Silicon Valley, 1.27 points. $)^{9}$

Finally, Hypothesis $2 \mathrm{c}$ posited that hoarding labor, even if it means retraining and relocation, is always fair. In fact, hoarding was rated between acceptable and completely fair, not substantively different from the rating on gentle layoffs.

What aspects of the "gentler" scenario matter? A small follow-up study examined what components of the "gentle" layoffs scenario matter. ${ }^{10}$ The sample was riders on BART (the local public transportation system) trains during the morning commute hours. This nonrandom sample was highly likely to be employed. Surveyors asked a sample of 30 respondents a baseline question where a company has a higher productivity due to the introduction of some new technology, thus the company is laying off some high-technology engineers (similar to Scenario E in the main survey). Results with gentle layoffs were similar to those in our larger Silicon Valley telephone survey, with a mean near 2.3 -- between completely fair and acceptable. A second group of 30 were asked a similar scenario but with severance pay added. Severance pay alone (that is, without job-hunting assistance or any reason to believe the layoff was likely) led to a slightly lower level of perceived fairness, 2.0. (With a sample size of only 30 per condition, this difference was not significant.) In contrast, a third group of respondents in the condition when employees who knew the layoffs were likely but were not given severance pay thought the layoffs were unfair (mean of 1.4).

\footnotetext{
${ }^{9}$ Gentle - harsh in Silicon Valley $=1.14$ points $[2.12$ gentle $(\mathrm{M})-0.98$ harsh $(\mathrm{F})]$ when the shock is generated by a demand shift, 0.86 points $[1.82$ gentle (I) - 0.96 harsh (L)] when due to employee suggestions, 1.27 points [2.30 gentle (E) - 1.03 harsh (D)] with new technology, and 0.65 [1.89 gentle (J) 1.24 harsh (S)] for a project end. For Canada, 1997, these differences are 1.63, 1.36, 1.32, and 1.53.

${ }^{10}$ The follow-up was created and collected by Elita Cheung, Brian Clinkenbeard, Bonnie Lin, Carol Lo, and Karen Wong as part of a Business Administration class at U.C. Berkeley, Spring 1998.
} 
Both the small sample size and the sample that differs from the telephone survey limit confidence in the results. Nevertheless, these results are consistent with the hypothesis that severance pay, not the lack of surprise, is responsible for most of the 1.3 point gap in perceived fairness between gentle and harsh layoffs. In related results, Rousseau and Anton (1988) found that a history of layoffs mattered less than severance pay in perceived fairness of layoffs; in contrast, Rousseau and Aquino (1993) found that advance notice was quite important. Brockner, et al. (1994) also found in his samples of layoff victims and survivors that advance notice increased perceptions of fairness.

\section{The Role of CEO Bonuses}

Theories of upward equity comparisons and theories of procedural justice lead to the prediction that layoffs were perceived as more fair when the CEO shares in the pain of downsizing than when the CEO receives a bonus for successful downsizing (Hypotheses $3 \mathrm{a}$ and $3 b)$.

Supporting hypothesis $3 \mathrm{a}$, respondents felt layoffs were substantially more fair when the CEO refused his bonus than when CEO pay was not mentioned (1.48 vs. $1.00, \mathrm{p}<.01$; only asked in U.S.). We also find some support for hypothesis $3 \mathrm{~b}$ : paying the $\mathrm{CEO}$ a bonus did significantly affect perceptions of fairness ( $p<.05$, Wilcoxon test), although the difference was relatively modest.

\section{The Role of Skill Specificity and Occupation}

As expected (hypothesis 4a), layoffs of employees with generally useful skills was slightly more fair than layoffs when the employees are specialists in this company's unusual technology, with an average of ten years tenure at this employer (gap of 0.17 in the U.S., $\mathrm{P}<.05$; not asked in Canada).

The results for occupation were mixed (hypothesis $4 b$ ). As hypothesized, laying off production workers is slightly more fair than laying off professionals in Canada (.95 vs. 1.12, p < .05 , Wilcoxon test). The gap was smaller and not significant in the U.S. (1.11 vs. 1.18 in U.S).

\section{Comparing Canada vs. Silicon Valley}

Averaging over all matched scenarios, respondents in Silicon Valley rated layoffs as nearly identically as fair as did respondents in Canada (a difference of 0.004 points). This provides no support for hypothesis 5a that Silicon Valley respondents would be more accepting of layoffs than Canadians.

Silicon Valley respondents thought hoarding labor and "gentle" layoffs were less fair than Canadians by about $1 / 2$ point on a 3 -point scale $(\mathrm{p}<.01)$, while Canadians found harsh layoffs 
about .17 points less fair $(\mathrm{p}<.01)$. Other differences between the two nations were both small and not statistically significant.

Hypothesis $5 \mathrm{~b}$ posited an interaction, where layoffs of professionals would be relatively more acceptable in Silicon Valley than in Canada. The divergences are in the hypothesized direction, but the results were small and not statistically significant.

A companion study asked questions concerning the fairness of pay cuts in Canada vs. Silicon Valley (Charness and Levine, 1998). As with the questions reviewed here on layoffs, Canadians were not more accepting of pay cuts than Silicon Valley respondents were on average. Also paralleling results here, some differences existed in which justifications were convincing. Nevertheless, the main result across both studies is that Canadian and Silicon Valley respondents have quite similar views on what justifies layoffs and pay cuts.

\section{Discussion}

As we expected, layoffs due to lower product demand are perceived as more fair than layoffs caused by employee suggestions. This result appears to be solely due to norms of reciprocity (not punishing employees for their efforts), not norms of sharing rents, as new technology was also considered a somewhat legitimate justification for layoffs. That is, to the extent that technological change also raised the employer's ability to pay, norms of rentsharing should make layoffs after technical changes unfair.

Although it was our intention that the technological change be viewed as factor that would increase an employers' ability to pay, respondents may have considered the technological changes as necessary to keep up. If the new technologies were available to the entire industry, then the company may have had to adopt them just to stay in business. In that case, the technology shock may reduce employment demand without increasing ability to pay, leading to these results. Further research may want to distinguish labor-saving technological shocks that give a company a competitive advantage and, thus, raise ability to pay vs. those technological changes that do not increase ability to pay.

As we expected, "gentle" layoffs with advance notice, and job-hunting assistance, and severance pay were considered more fair than harsh layoffs with no notice. Unexpectedly, hoarding labor was not considered fairer than gentle layoffs. Evidently, a significant proportion of respondents felt that requiring relocation to maintain employment was not completely fair.

As we expected, layoffs were perceived as more fair if the CEO shared the pain. Unexpectedly, there was no statistically significant reduction in perceived fairness if the CEO received a record bonus for success in cutting costs. This result was not what we expected because both norms of distributive justice (sharing good and bad times) and norms of procedural justice (decision-makers should be impartial and not benefit from a decision that harms others). 
Moreover, these justice theories had received support from both case study and statistical evidence on within-firm pay differentials (see the evidence and citations in Cowherd and Levine, 1992).

It is common for CEOs to receive bonuses based on accounting measures of costs and profits. In addition, many studies find that people tend to perceive what is usual as reasonably fair. The combination of these two factors may lead respondents to consider CEO bonuses as usual enough not to be upsetting; that is, the "Accept what is normal" heuristic outweighs the violation of the procedural justice norms of impartiality due to the CEO benefiting from the layoff that harms employees. Alternatively, people may feel that in general rewarding the CEO for cost cutting is fair, and the question may not have made salient that the reduction in costs was directly tied to downsizing.

Layoffs of production employees and of employees with general skills were slightly more fair than layoffs of professionals and employees with firm-specific skills. None of these effects were large, consistent with the results in Rousseau and her co-authors. Specifically, Rousseau and Aquino (1993) found that seniority had a small statistically significant effect on fairness, while Rousseau and Anton (1988) found that employability (ease of finding the next job) had no effect. Overall, people appear to give some weight to seniority and employees' cost of job loss, but not a lot.

Contrary to expectations, layoffs were not on average more accepted in Silicon Valley. Canadian respondents were less accepting of harsh layoffs but more accepting of gentle layoffs than were those in Silicon Valley. Given that we selected Silicon Valley specifically with the intent of finding regional differences, these results suggest that U.S.-Canada gap in attitudes towards the market may not be that large. Lipset (1990) surveys the larger literature on U.S.Canada gaps in attitudes; he finds many cases of differences and many cases of similarity. As our respondents were in anglophone Canada, we are unable to say whether respondents in Quebec would be more different from U.S. respondents.

\section{Implications}

Discussions in the managerial and popular press often stress the "new employment contract." The story goes that the old employment contract had rigid wages and employment. In contrast, under the new contract, employers pay market wages and freely lay off surplus employees.

For managers, the results in this paper suggest that traditional internal labor market policies such as minimizing layoffs may still be useful in promoting high levels of skill and effort. Moreover, when layoffs are necessary, it appears that providing a justification from an exogenous source, having top executives share the pain, and providing notice and assistance all can improve 
perceptions of fairness. These results echo prescriptions found elsewhere in the literature (e.g., Brockner, 1992).

Canadians' reputation for norms that were less responsive to the market than U.S. citizens may have dissuaded some managers from choosing to site new workplaces in Canada. For managers, these results suggest that U.S. respondents in one of the most market-oriented portions of the nation had similar norms to anglophone Canadians. Thus, these results suggest that concerns about an attitude gap may not be warranted.

For public policy makers, these results suggest that labor-market policies should not abandon hopes of long-term stable jobs. Product market and organizational forces may keep the supply of such jobs below demand, but employees apparently have rather traditional ideas about what is fair treatment.

For scholars of psychological employment contracts and of fairness theories these results pose several puzzles. For example, no theory of justice predicted that a CEO who shares the pain can increase perceptions of fairness, but a CEO who receives a bonus does not reduce fairness by much. Why is the gap between the perceived fairness of gentle and harsh layoffs so much greater in Canada than in the U.S.? Is it possible that the implicit contract is clearer in Canada, so that responses tend to be more bipolar? Our indication that norms of reciprocity may be more important than rentsharing has direct bearing on current models of non-pecuniary utility (e.g., Rabin, 1993; Bolton and Ockenfels, 1997; Fehr and Shmidt, 1997; Charness and Rabin, 1999).

\section{Limitations and Further Research}

This study is subject to a number of limitations, each of which suggests additional possible research.

Most importantly, people's responses to hypothetical surveys may differ from attitudes of employees in a real layoff situation. It is important to use alternative methods to check the validity of these findings. For example, researchers could survey victims or survivors of layoffs or measure behaviors of survivors in cases that are similar to these scenarios. More plausibly, researchers could create scenarios that match somewhat similar pairs of real-life situations, and see whether survey results from people in the actual situations similar to those of a quasi-experiment. ${ }^{11}$ The match between several of our results (when conditions overlapped) and those of Brockner and his co-authors (1994) is reassuring, as they surveyed actual layoff survivors and victims, while we surveyed a random sample.

Our findings of modest differences over between the U.S. and Canada lead to more questions. First, if we were to extend the range of cultures, would fairness perceptions diverge

\footnotetext{
${ }^{11}$ We thank an anonymous referee for this suggestion.
} 
further? (We are currently engaged in replicating and extending these findings to additional continents.) Extensions over time are important as well, to see if increases in the unemployment rate decrease perceptions of the fairness of layoffs as the cost of job loss rises, increase the perception of fairness as people become accustomed to layoffs, or have little effect because perceptions are due to more persistent cultural values.

The scenarios we presented included multiple features. It would be useful to have more scenarios so we could determine which elements of the "gentler" layoffs make a difference: advance notice, severance pay, or only the combination? The sources of shocks can also be further broken down. For example, the technology shock condition can specify either a companyspecific shock (implying an increase in the employers' ability to pay) or an industry-wide shock, so that adoption is necessary for corporate survival. With more detailed scenarios one could examine Brockner, et al.'s (1994) hypothesis that either low cost of job loss or high procedural justice is sufficient for respondents to feel a layoff is fair.

Finally, this survey did not collect demographic information on respondents. It is possible that respondents in one region had very different occupation mix than in another, and that if conditioned on occupational mix that regional gaps would arise. More generally it would be useful to see how answers differ according to the differences of the respondent. For example, Gorman and Kehr (1988) find that top managers are much more likely to accept pay cuts as fair than does a random sample of citizens. In the realm of layoffs (which are much more common than pay cuts), we need to know how much managers and their subordinates share a common vision of what is fair. Again, the rationale for the differences is also important. It may be that managers perceive pay cuts as fair in large part because they feel pay cuts can avoid layoffs, while other respondents have lower confidence in such a link. 


\section{REFERENCES}

Academy of Management, Executive, special issue on "Careers in the $21^{\text {st }}$ Century," November 1996.

Akerlof, George, "Labor Contracts as Partial Gift-Exchange," Quarterly Journal of Economics, 1982, Vol. 97, pp. 543-569.

Akerlof, George and Janet Yellen, "The Fair Wage-Effort Hypothesis and Unemployment," Quarterly Journal of Economics, 1990, Vol. 105, pp. 255-283.

Baker, George, Michael Jensen, and Kevin Murphy, "Compensation and Incentives: Theory versus Practice," Journal of Finance, July, 1988, pp. 593-616.

Barnard, Chester, The Functions of the Executive, Harvard University Press, Cambridge MA, 1938.

Becker, Gary, Human Capital, 2nd ed., University of Chicago Press, 1975.

Belman, Dale and David I. Levine, "Have Internal Labor Market Wage Structures Declined in Large Employers?" mimeo, University of California, 1998.

Bewley, Truman, "A Field Study of Downward Wage Rigidity," mimeo, Yale University, 1995. (A brief version appeared as "A Depressed Labor Market as Explained by Participants," American Economic Review, 1995 May, v. 85 n. 2, pp. 250-254.

Bies, Robert J., Thomas M. Tripp, and Margaret A. Neale, "Procedural Fairness and Profit-Seeking: The Perceived Legitimacy of Market Exploitation," Journal of Behavioral Decision Making, 6, 4, 1993 : 243-256.

Bishop, Elizabeth, and David I. Levine, "Computer Mediated Communication as Employee Voice: A Case Study," Industrial and Labor Relations Review, 1998.

Blau, Peter M., Exchange and Power in Social Life, J. Wiley, New York, 1964.

Bolton, Gary, and Axel Ockenfels, "ERC:A Theory of Equity, Reciprocity, and Competition," mimeo, 1997

Brockner, Joel, "Managing the Effects of Layoffs on Survivors," California Management Review, 34, 2 (Winter 1992): 9-28.

Campbell, Carl M., and Kunal Kamlani, "The Reasons for Wage Rigidity: Evidence from a Survey of Firms," mimeo, Dartmouth College, 1995.

Cappelli, Peter, and others, Change at Work, Oxford University, New York, 1997.

Card, David and Richard B. Freeman (eds.), Small differences that matter : labor markets and income maintenance in Canada and the United States, Chicago : University of Chicago Press, 1993.

Charness, Gary B., "Attribution and Reciprocity in a Simulated Labor Market: An Experimental Investigation," Universitat Pompeu Fabra Working Paper no. 283, 1998

Charness, Gary, and David I. Levine, "Changes in the Employment Contract: Evidence from a QuasiExperiment," mimeo, U.C. Berkeley, 1998.

Charness, Gary, and Matthew Rabin, "Social Preferences: Some Simple Tests and a Model," mimeo, 1999

Cowherd, Douglas, and David I. Levine, "Product Quality and Pay Equity Between Low- Level Employees and Top Management: An Investigation of Distributive Justice Theory," Administrative Science Quarterly, 37, 2, June 1992, pp. 302-320.

Dial, Jay, and Kevin J. Murphy, "Incentives, downsizing, and value creation at General Dynamics," Journal of Financial Economics, Mar 1995, 37(3):261-314.

Farber, Henry S., "Are Lifetime Jobs Disappearing? Job Duration in the United States: 1973-1993" NBER Working Paper No. 5014, 1995.

Farber, Henry, "The Changing Face of Job Loss in the United States, 1981-1993," NBER w.p. 5596, 1996.

Farh, Jiing-Lih, Philip M. Podsakoff and Dennis W. Organ, "Accounting for Organizational Citizenship Behavior: Leader Fairness and Task Scope Versus Satisfaction," Journal of Management, 16, 4 (Dec 1990):705-721.

Fehr, Ernst, Georg Kirchsteiger, and Arno Riedl, "Does Fairness Prevent Market Clearing? An

Experimental Investigation," Quarterly Journal of Economics, 1993, Vol. 108, pp. 437-459

Fehr, Ernst, and Klaus Schmidt, "A Theory of Fairness, Competition, and Cooperation, mimeo, 1997 
Fehr, Ernst, Erich Kirchler, Andreas Weichbold, and Simon Gachter, "When Social Forces Overpower Competition: Gift-Exchange in Experimental Labor Markets" Journal of Labor Economics, 1998, Vol 16, pp. 437-459

Foulkes, Fred, Personnel Policies in Large Nonunion Companies, Prentice Hall, Englewood Cliffs, NJ, 1980. Gouldner, Alvin, 1954. Patterns of Industrial Bureaucracy. New York: Free Press.

Gorman, Raymond, and James B. Kehr, "Fairness as a Constraint on Profit-Seeking: Comment," American Economic Review, 82, n. 1, March 1992, pp. 355-358.

Hackett, Brian, The New Deal in Employment Relationships, Conference Board publication 1162, Aug 13, 1996.

Kahneman, Daniel, Jack Knetsch, and Richard Thaler, "Fairness as a Constraint on Profit-Seeking: Entitlements in the Market," American Economic Review, 1986, Vol. 76, pp. 728-741.

Konovsky, Mary A; Pugh, S Douglas, "Citizenship behavior and social exchange," Academy of Management Journal 37, (Jun 1994): 656-669.

Leventhal, Gerald S., 1976 "The distribution of rewards and resources in groups and organizations." In L. Berkowitz and E. Walster (eds.), Advances in Experimental Social Psychology, 9: 91-131. New York: Academic Press.

Lehmann, Donald R., Sunil Gupta and Joel H. Steckel,_Marketing Research_, Addison Wesley, Reading MA, 1998.

Levine, David I. "What Do Wages Buy?" Administrative Science Quarterly, 38, 3, September, 1993, pp. 462-483.

Levine, David I. "Fairness, Markets, and Ability to Pay: Evidence From Compensation Executives." American Economic Review, vol. 83, no. 5 (December, 1993) pp. 1241-1259.

Lind, E. Allan, and Tom R. Tyler, The social psychology of procedural justice, New York : Plenum Press, 1988.

Lipset, Seymour Martin, Continental divide: the values and institutions of the United States and Canada, New York, Routledge, 1990.

MacKenzie, Scott B, Philip M. Podsakoff, , and Michael Ahearne, "Some possible antecedents and consequences of in-role and extra-role salesperson performance," Journal of Marketing, 62, 3 (Jul 1998): 87-98.

MacKenzie, G.B., P.M. Podsakoff, and R. Fetter (1991), "Organizational citizenship behavior and objective productivity as determinants of managerial evaluations of salespersons' performance," Organizational Behavior and Human Decision Processes, 50, 123-50.

Milgrom, Paul and John Roberts, Economics, Organization, and Management, Prentice Hall, New Jersey, 1992.

Moorman, Robert H., "Relationship Between Organizational Justice and Organizational Citizenship Behaviors: Do Fairness Perceptions Influence Employee Citizenship?" Journal of Applied Psychology, 76, 6 (Dec 1991): 845-855.

Neumark, David, Daniel Polsky, and Daniel Hansen, "Has Job Stability Declined Yet? New Evidence for the 1990's" NBER Working Paper No. 6330, 1997.

Organ, D.W., Organizational citizenship behavior: The good soldier syndrome, Lexington, MA: DC Heath, 1988.

O'Shaughnessy, K.C., David I. Levine, and Peter Cappelli, "Changes in Managerial Pay Structures 1986-1992: Tests of Human Capital and Other Explanations," working paper 67B, Institute of Industrial Relations, UC Berkeley, 1998.

Podsakoff, Philip M, Michael Ahearne, and Scott B. MacKenzie, "Organizational citizenship behavior and the quantity and quality of work group performance," Journal of Applied Psychology, 82, 2 (Apr 1997): 262-270.

Rabin, Matthew, "Incorporating Fairness into Game Theory and Economics," American Economic Review, 1993 Dec., v. 83, n. 5, pp. 1281-1302.

Rose, Stephen, “The Decline of Employment Stability in the 1980s," National Commission on Employment Policy, Washington DC, 1995.

Rousseau, Denise M., Psychological contracts in organizations: understanding written and unwritten agreements, Thousand Oaks: SAGE Publications, 1995. 
Rousseau, Denise M., and R.J. Anton, "Fairness and implied contract obligations in job terminations: A policy-capturing study, Human Performance, v. 1, 273-289, 1988.

Rousseau, Denise M., and R.J. Anton, "Fairness and implied contract obligations in job terminations: The role of contributions, promises and performance," Journal of Organizational Behavior, 12, 1991, 287299.

Rousseau, Denise M., and K. Aquino, "Fairness and implied contract obligations in job terminations: The role of remedies, social accounts, and procedural justice," Human Performance, v. 6, 1993, 135-149.

Sculley, John, Odyssey: Pepsi to Apple, Harper and Rowe, NY, 1987.

Shore, Lynn McFarlane, and Lois E. Tetrick, "The Psychological Contract as an Explanatory Framework in the Employment Relation," in Trends in Organizational Behavior, vol. 1, C.L. Cooper and D. M. Rousseau, eds, John Wiley, 1994.

Siegel, Sidney, and N. John Castellan, Nonparametric Statistics for the Behavioral Sciences, McGraw-Hill, New York, 1988

Simon, Herbert A., "Organizations and Markets," Journal of Economic Perspectives, Spring 1991, pp. 25-44 Williamson, Oliver E., Markets and Hierarchies, Free Press, New York, 1975. 


\section{Appendix 1: The Survey Questions}

This study presents 19 questions about layoffs. All were asked in Silicon Valley, while 11 of these questions were also asked in Canada. Surveys were designed so that no respondent was asked closely comparable questions; 3 or 4 questions were asked in each phone interview.

All questions involved scenarios where, due to some "shock," an employer was laying off a worker. The employees could be either high-technology engineers or production workers. The layoff could be gentle, harsh, or even labor hoarding. Workers developed either employer-specific or generally useful skills. In Silicon Valley, some questions included mention of a CEO either receiving a record bonus or refusing a bonus.

The first sentence in every survey question describes why the layoff is occurring:

a1) "A company faced lower product demand due to shifts in the market; the viability of the employer was threatened.î

a2) ìA company has higher productivity due to the introduction of some new technology.î

a3) ìA company has higher productivity due to the employees' suggestions.î

a4) iThe current project for a group of high-technology engineers [a $4^{\prime}$ : production workers] has ended. The company has decided to lay them off.î

The next sentence (except in the case of $\mathrm{a} 4$ or $\mathrm{a}^{\prime}{ }^{\prime}$ above) describes the type of worker being laid off:

b1: îThus, the company is laying off some high-technology engineers.î

b2: îThus, the company is laying off some production workers.î

The next sentence mentions the type of skills developed by the affected workers:

c1) ìThese workers are specialists in this company's unusual technology, with an average of ten years tenure at this employer.î

c2) îThe affected engineers [production workers] have an average of ten years tenure at this employer and specialize in widely used hardware, so that their skills would be useful in another job.

The next sentence states the employerís response to the shock:

d1: ìThe company is laying off the employees with two weeks' warning. These are the first layoffs in the company's history.î

$\mathrm{d} 2$ : ìBefore the layoff, the employer gave each employee four paid weeks to find another job elsewhere in the company. Those who could not find a new position received severance pay based on age and years of service. The company provided out-placement service including counseling and resume-writing workshops. Employees knew layoffs were likely in this circumstance. $\hat{1}$ 
d3: ìAlthough the company has a surplus of workers, it has decided to keep a set of hightechnology engineers [production workers] on the payroll until work can be found for them. The company may shift the workers to a new line of work, and may require them to relocate.1̂

Finally, a CEO bonus might be mentioned:

e1) No mention.

e2) iThe CEO received a record bonus for his success in cutting costs [introducing the new technology].î

e3) îThe CEO turned down his bonus this year because of the unexpected need for layoffs.î

The 19 questions consist of concatenations of these sentences, in the following combinations:
A. a1, b1, c2, d1, e1
B. a4, c2, d1, e1
C. a1, b1, c1, d1, e3
D. a2, b1, c1, d1, e1
E. a2, b1, c1, d2, e1
F. a1, b1, c1, d1, e1
G. a4, c1, d1, e1
$\mathrm{H} \quad \mathrm{a} 1, \mathrm{~b} 1, \mathrm{c} 1, \mathrm{~d} 1, \mathrm{e} 2$
I. a3, b1, c1, d2, e1
J. a4, c1, d2, e1
K. a1, b2, c1, d1, e1
L. a3, b1, c1, d1, e1
M. a1, b1, c1, d2, e1
N. a2, b1, c1, d1, e3
O. a4, c2, d1, e1
P. a1, b1, c1, d3, e1
Q. $\quad a 2, b 1, c 1, d 1, e 2$
R. a1, b2, c2, d1, e1
S. a4, c1, d1, e1

For example, question I is:

ìA company has higher productivity due to the employees' suggestions. Thus, the company is laying off some high-technology engineers. These workers are specialists in this company's unusual technology, with an average of ten years tenure at this employer. Before the layoff, the employer gave each employee four paid weeks to find another job elsewhere in the company. Those who could not find a new position received severance pay based on age and years of service. The company provided out-placement service including counseling and resume-writing workshops.

Employees knew layoffs were likely in this circumstance.î

Questions A, B, C, H, N, O, Q, and R were asked only in Silicon Valley. 


\section{Appendix 2: Results}

The number of respondents who gave each response for perceived fairness of the scenario. $\mathrm{C}=$ Completely fair ( 3 in calculations presented in the text); $\mathrm{A}=$ Acceptable (2); $\mathrm{U}=$ slightly Unfair (1); and V = very unfair (0).
A. Demand shock, Harsh Layoffs,
$\begin{array}{llllll}8 & 34 & 64 & 31 & 1.14\end{array}$
Professionals, General Skills
B. Project end, Harsh Layoffs,
$\begin{array}{lllll}15 & 49 & 50 & 19 & 1.45\end{array}$
Production, General Skills
C. Demand shock, Harsh Layoffs,
$\begin{array}{lllll}11 & 49 & 40 & 21 & 1.41\end{array}$
Professionals, Special Skills, CEO
refused bonus
D. New technology, Harsh Layoffs,
Professionals, Special Skills
E. New technology, Gentle Layoffs,
Professionals, Special Skills
F. Demand shock, Harsh Layoffs,
Professionals, Special Skills
G. Project end, Harsh Layoffs,
Production, Special Skills
H. Demand shock, Harsh Layoffs,
Professionals, Special Skills, CEO record
bonus
I. Employees' Suggestions, Gentle
$\begin{array}{lllll}45 & 35 & 23 & 8 & 2.05\end{array}$
$\begin{array}{lllll}32 & 69 & 17 & 20 & 1.82\end{array}$
Layoffs, Professionals, Special Skills
J. Project end, Gentle Layoffs,
$\begin{array}{lllll}2 & 26 & 56 & 39 & 0.93\end{array}$
$\begin{array}{lllll}8 & 21 & 55 & 34 & 1.03\end{array}$
$\begin{array}{lllll}50 & 49 & 15 & 3 & 2.25\end{array}$
$\begin{array}{lllll}67 & 53 & 10 & 8 & 2.30\end{array}$
$\begin{array}{lllll}5 & 27 & 59 & 48 & 0.92\end{array}$
$\begin{array}{lllll}5 & 22 & 58 & 35 & 0.98\end{array}$
$\begin{array}{lllll}8 & 32 & 42 & 27 & 1.19\end{array}$
$9 \begin{array}{lllll}9 & 33 & 55 & 26 & 1.20\end{array}$
Professionals, Special Skills
K. Demand shock, Harsh Layoffs,
Production, Special Skills
L. Employees' Suggestions, Harsh
Layoffs, Professionals, Special Skills
M. Demand shock, Gentle Layoffs,
Professionals, Special Skills
N. New technology, Harsh Layoffs,
Professionals, Special Skills, CEO
refused bonus
O. Project end, Harsh Layoffs,
$\begin{array}{lllll}9 & 25 & 43 & 57 & 0.90\end{array}$
Professionals, General Skills
P. Demand shock, Hoard labor,
Professionals, Special Skills
Q. New technology, Harsh Layoffs,
$\begin{array}{llllllllll}61 & 44 & 3 & 1 & 2.51 & 36 & 64 & 19 & 16 & 1.89\end{array}$
$\begin{array}{llllllllll}4 & 30 & 55 & 30 & 1.07 & 7 & 32 & 73 & 25 & 1.15\end{array}$
$\begin{array}{llllllllll}1 & 11 & 53 & 48 & 0.69 & 14 & 20 & 53 & 53 & 0.96\end{array}$
$\begin{array}{llllllllll}77 & 50 & 3 & 1 & 2.55 & 62 & 40 & 16 & 15 & 2.12\end{array}$
$\begin{array}{lllll}25 & 34 & 51 & 16 & 1.54\end{array}$
$\begin{array}{lllll}17 & 60 & 39 & 19 & 1.56\end{array}$
$\begin{array}{llllllllll}16 & 8 & 0 & 0 & 2.67 & 40 & 65 & 27 & 6 & 2.01\end{array}$
$\begin{array}{lllll}19 & 19 & 31 & 69 & 0.91\end{array}$

Canada

Silicon Valley

C A U V Mean

C A U V Mean

Professionals, Special Skills, CEO record 
bonus

R. Demand shock, Harsh Layoffs,

$\begin{array}{lllll}22 & 30 & 33 & 50 & 1.18\end{array}$

Production, General Skills

S. Project end, Harsh Layoffs,

$\begin{array}{lllll}6 & 25 & 37 & 39 & 0.98\end{array}$

$\begin{array}{lllll}21 & 29 & 49 & 38 & 1.24\end{array}$

Professionals, Special Skills 